\title{
Aphid parasitoids that occur on wheat crops of Northeast of the Parana State with recovery of Aphidius rhopalosiphi in Brazil
}

\section{Parasitoides de pulgões-do-trigo que ocorrem no Norte do estado do Paraná e recaptura de Aphidius rhopalosiphi no Brasil}

\author{
Orcial Ceolin Bortolotto ${ }^{1 *}$; Ayres de Oliveira Menezes Júnior²; \\ Marcus Vinícius Sampaio; ; Adriano Thibes Hoshino ${ }^{4}$
}

\begin{abstract}
Aphids (Hemiptera: Aphididae) are the main pest of wheat (Hemiptera: Aphididae) in several countries. In Brazil, the Biological Control of Wheat Aphids released millions of aphid parasitoids (Hymenoptera: Braconidae and Aphelinidae) on wheat fields and in the present moment the chemical control is rarely necessary. However, since the 80 's few studies was carried out to evaluate the species established in Brazil. For this reason, the aim of this study was to record the species of aphid parasitoids that occur in wheat in the northern region of Parana state, Brazil. Four commercial wheat fields were investigated in the agricultural years of 2008 and 2009. The aphid parasitoids were captured with traps (Moericke and Malaise) and aphid mummified were collected. In total, six species of parasitoids were found, Aphidius colemani, A. uzbekistanicus, A. ervi, Aphidius rhopalosiphi, Diaeretiella rapae e Lysiphlebus testaceipes. These results contribute with the register of three exotic species in Parana, and confirm the establishment of $A$. rhopalosiphi in the country. We emphasize the need for further studies in other regions of the country, as other species introduced also need to have their establishment confirmed.
\end{abstract}

Key words: Aphids, natural parasitism, Aphidiinae, biological control agents

\section{Resumo}

Os pulgões (Hemiptera: Aphididae) são pragas de extrema importância em cereais de inverno no mundo todo. No Brasil, o programa Controle Biológico de Pulgões do Trigo liberou milhões de parasitoides (Hymenoptera: Braconidae e Aphelinidae) nas áreas tritícolas, reduzindo expressivamente a população da praga, e atualmente raramente o controle químico se faz necessário. Entretanto, desde a década de 80 poucos trabalhos de campo tem sido realizados para verificar as espécies efetivamente estabelecidas no País. Por esta razão, este estudo objetivou registrar as espécies de parasitoides de pulgões ocorrentes em lavouras de trigo na região Norte no Paraná. O trabalho foi realizado em quatro áreas comerciais de trigo, durante as safras 2008 e 2009. A captura dos parasitoides ocorreu com uso de armadilhas (Moericke e Malaise) e coleta de pulgões mumificados. No total foram encontradas seis espécies de parasitoides, Aphidius colemani, A. uzbekistanicus, A. ervi, Aphidius rhopalosiphi, Diaeretiella rapae e Lysiphlebus testaceipes. Esses resultados contribuem com a comprovação do estabelecimento de três espécies exóticas de parasitoides de pulgões no Paraná, e confirma o estabelecimento de A. rhopalosiphi no País. Ressalta-se a necessidade de estudos complementares em outras regiões do País, pois outras espécies introduzidas necessitam ter o estabelecimento comprovado.

Palavras-chave: Afídeos, parasitismo natural, Aphidiinae, agentes de controle biológico

\footnotetext{
Discente de Doutorado da Universidade Estadual de Londrina., UEL, Londrina, PR. E-mail: bortolotto.orcial@gmail.com Prof. Dr. do Dept ${ }^{\circ}$ de Agronomia, UEL, Londrina, PR. E-mail: ayres@uel.br

Prof. da Universidade Federal de Uberlândia, UFU, Uberlândia, MG. E-mail: mvsampaio@iciag.ufu.br

Discente de Mestrado, UEL, Londrina, PR. E-mail: hoshinoagro@gmail.com

Author for correspondence
} 
Aphids (Hemiptera: Aphididae) are the main pest of wheat (Hemiptera: Aphididae) in several countries. In Brazil, these insects caused damage to winter cereals until the late 1970s, when Embrapa Wheat successfully implemented the Biological Control of Wheat Aphids (BCWA) program (SALVADORI; SALLES, 2002).

However, after the introduction of the parasitoids, few studies were conducted on agroecosystem to identify the species established in Brazil. For example, Aphidius rhopalosiphi De Stefani-Perez, 1902, Ephedrus plagiator (Nees, 1811) and Praon gallicum Starý, 1971 were captured only in the early 1980s. Consequently, it is not known whether these species are established in Brazil or whether their capture resulted from their frequent field releases as part of the BCWA (STARÝ; SAMPAIO; BUENO, 2007). Recently, Alves et al. (2005) and Zanini et al. (2006a, b) reported the occurrence of Lysiphlebus testaceipes (Cresson, 1880) and Aphidius colemani Viereck, 1912 in west Parana, on Rhopalosiphum padi (Linnaeus, 1758) and Sitobion avenae (Fabricius, 1794) hosts aphids. Both aphid parasitoids are native, what can explain the capture, but the researches didn't find exotic species introduced by BCWA.

Thus, this study aimed to record the occurrence of parasitoids (Hymenoptera: Braconidae: Aphidiinae) on wheat crops in the north of Parana state in an attempt to contribute to the knowledge of the species of parasitoids effectively established in Brazil.

The investigation was conducted in four commercial wheat fields from May to August of 2008 and from June to September of 2009 in the north of Parana state, Brazil. In 2008, the insects were collected in Ibiporã - Sítio Santo Antônio

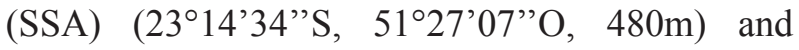
Londrina ( $23^{\circ} 20^{\prime} 23^{\prime}$ 'S, $\left.51^{\circ} 12^{\prime} 32^{\prime \prime} \mathrm{W}, 532 \mathrm{~m}\right)$, and in 2009 , parasitoids were also collected in Ibiporã -

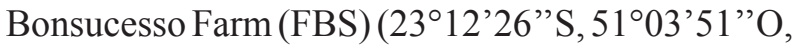

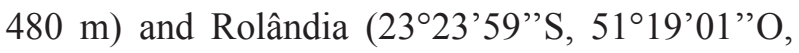
$650 \mathrm{~m})$. The survey comprised direct sampling of parasitized aphids on plants and the capture of adult parasitoids with traps. Adult parasitoids were captured with Moericke (yellow color) and Malaise traps in 2008 and 2009, respectively. The Moericke traps (40 units) contained water, detergent and salt. This trap was placed at ground level, between crop rows, and in each field in an area of $6,000 \mathrm{~m}^{2}$ and left in place for two days per week. Eleven and nine samples were collected in Ibiporã-SSA and Londrina, respectively. In 2009, two Malaise traps were set $500 \mathrm{~m}$ apart in each area. A flask with $70 \%$ alcohol was placed on top of each trap for insect collection and changed weekly. All specimes captured were identified in laboratory, in specie level. Also, parasitized hosts were collected by inspecting whole plants, from early growth to the ripening stage of wheat plants. A total of 800 and 400 wheat tillers were evaluated every week in 2008 and 2009, respectively. Each collected parasitized host was individualized in a gelatin capsule until the emergence of the parasitoid. All mummies were identified in laboratory, at specie level, using a stereoscopic microscope.

A total of 1,270 parasitized hosts and six species of parasitoids were captured in the two-year period, and all species belonging to Braconidae family. In 2008, five species were observed in the direct evaluation and the same species were captured with the Moericke trap (Tables 1 and 2). In IbiporãSSA, 392 parasitoids were trapped, with greater abundance of $L$. testaceipes (57\%), followed by $A$. ervi (22\%), A. colemani (15\%), Diaeretiella rapae (M'Intosh, 1855) (4\%), and Aphidius uzbekistanicus Luzhetski, 1960 (2\%). In Londrina, 95 parasitoids were captured, with a greater abundance of $A$. colemani (51\%), followed by L. testaceipes (31\%), and $D$. rapae $(18 \%)$.

The parasitoids A. ervi and A. uzbekistanicus were not captured with the Moericke trap, probably because collection was stopped when the crop bloomed, before the greatest infestation of Sitobion avenae (Fabricius), the preferential host of these parasitoids in wheat (Table 1). Among the parasitized hosts collected in 2009, we observed the emergence of six species of parasitoids in IbiporãSSA, and five in Londrina (Table 1). 
Table 1. Parasitoids emerged from host aphids from commercial wheat fields in Ibiporã-SSA (Sítio Santo Antônio) and Londrina, Parana ( $\mathrm{n}=629$ and $\mathrm{n}=317$, hosts collected in the 2008 and 2009 agricultural years, respectively). Paraná, from May to August of 2008 and from June to September of 2009.

\begin{tabular}{|c|c|c|c|c|}
\hline \multirow[b]{2}{*}{ Location } & \multicolumn{4}{|c|}{2008} \\
\hline & $\begin{array}{l}\text { Rhopalosiphum } \\
\text { padi }\end{array}$ & $\begin{array}{l}\text { Schizaphis } \\
\text { graminum }\end{array}$ & R. maidis & Sitobion avenae \\
\hline \multicolumn{5}{|l|}{ Ibiporã SSA } \\
\hline Lysiphlebus testaceipes & 139 & 8 & 27 & - \\
\hline Diaeretiella rapae & 21 & - & - & - \\
\hline Aphidius colemani & 6 & 2 & - & - \\
\hline A. ervi & - & - & - & 83 \\
\hline A. uzbekistanicus & 3 & - & - & 3 \\
\hline \multicolumn{5}{|l|}{ Londrina } \\
\hline Aphidius ervi & - & - & - & 10 \\
\hline A. uzbekistanicus & - & - & - & 1 \\
\hline \multicolumn{5}{|c|}{2009} \\
\hline \multicolumn{5}{|l|}{ Ibiporã SSA } \\
\hline Lysiphlebus testaceipes & 68 & - & - & - \\
\hline Diaeretiella rapae & 1 & - & - & - \\
\hline Aphidius colemani & 2 & - & - & - \\
\hline A. ervi & - & - & - & 2 \\
\hline A. uzbekistanicus & - & - & - & 11 \\
\hline A. rhopalosiphi & - & - & - & 1 \\
\hline \multicolumn{5}{|l|}{ Londrina } \\
\hline Aphidius ervi & 3 & - & - & 10 \\
\hline A. uzbekistanicus & - & - & - & 16 \\
\hline A. colemani & 6 & - & - & 1 \\
\hline
\end{tabular}

$(-)=$ zero.

Source: Elaboration of the authors.

In Ibiporã-FBS and in Rolândia, we collected only 11 and 10 mummified hosts, respectively, and it was not possible to identify the parasitoids because the adults had not emerged. The Malaise trap captured a total of 23,300 parasitoids from six species in all the sampled areas. Aphidius colemani was the most abundant $(62.32 \%)$, followed by L. testaceipes $(26.38 \%)$, D. rapae $(\sim 7 \%)$, A. ervi $(\sim 0.93 \%)$, A. uzbekistanicus $(\sim 3.22 \%)$, and $A$. rhopalosiphi $(\sim 0.15 \%)$ (Table 2$)$. 
Table 2. Parasitoids captured with Moericke traps (agricultural year 2008) and Malaise trap (agricultural year 2009) in commercial wheat fields in Ibiporã-FSB (Bonsucesso Farm), Ibiporã-SSA (Sítio Santo Antônio), Londrina, and Rolândia. Paraná, from May to August of 2008 and from June to September of 2009.

\begin{tabular}{|c|c|c|}
\hline \multirow{2}{*}{ Location } & \multicolumn{2}{|c|}{ Trap (Year) } \\
\hline & Moericke (2008) & Malaise (2009) \\
\hline \multicolumn{3}{|l|}{ Ibiporã FBS } \\
\hline Lysiphlebus testaceipes & - & 656 \\
\hline Diaeretiella rapae & - & 150 \\
\hline Aphidius colemani & - & 2,277 \\
\hline A. ervi & - & 71 \\
\hline A. uzbekistanicus & - & 89 \\
\hline A. rhopalosiphi & - & 14 \\
\hline \multicolumn{3}{|l|}{ Ibiporã SSA } \\
\hline Lysiphlebus testaceipes & 217 & 1,961 \\
\hline Diaeretiella rapae & 16 & 803 \\
\hline Aphidius colemani & 60 & 321 \\
\hline A. ervi & 88 & 21 \\
\hline A. uzbekistanicus & 11 & 163 \\
\hline A. rhopalosiphi & 0 & 4 \\
\hline \multicolumn{3}{|l|}{ Londrina } \\
\hline Lysiphlebus testaceipes & 31 & 1,348 \\
\hline Diaeretiella rapae & 11 & 136 \\
\hline Aphidius colemani & 53 & 6,218 \\
\hline A. ervi & 0 & 50 \\
\hline A. uzbekistanicus & 0 & 240 \\
\hline A. rhopalosiphi & 0 & 5 \\
\hline \multicolumn{3}{|l|}{ Rolândia } \\
\hline Lysiphlebus testaceipes & - & 262 \\
\hline Diaeretiella rapae & - & 22 \\
\hline Aphidius colemani & - & 1,173 \\
\hline A. ervi & - & 5 \\
\hline A. uzbekistanicus & - & 41 \\
\hline A. rhopalosiphi & - & 1 \\
\hline
\end{tabular}

(-) Areas evaluated only in the 2009 agricultural year, without using the Moericke trap.

Source: Elaboration of the authors.

In the present study, $A$. colemani and $L$. testaceipes were the most abundant species in the field. These species were considered predominant in studies done in wheat fields in the west of Paraná State (ALVES et al., 2005, ZANINI et al., 2006a, b), and according to Starý, Sampaio and Bueno (2007), A. colemani, L. testaceipes, and D. rapae were also predominant in South America. The great host range of these species (SAMPAIO; BUENO; LENTEREN, 2001; SAMPAIO; BUENO; DE CONTI, 2008; SILVA, BUENO, SAMPAIO;
2008) may favor their adaptation to different agroecosystems.

Parasitoids A. uzbekistanicus and A. ervi were released in the west of Parana in the 1980s; however, recent studies carried out in the state have not reported their occurrence in wheat fields (ALVES et al., 2005; ZANINI et al., 2006a, b). The establishment of $A$. rhopalosiphi was confirmed in Brazil with 24 specimens captured with the Malaise trap, but only one individual emerged from parasitized $S$. avenae host (Table 2). Until the 
1980s, when BCWA was started, this species was found in great numbers in wheat fields in the south of Brazil (STARÝ; SAMPAIO; BUENO, 2007). However, after that, this species was not found in the field anymore, and its establishment in Brazil was questioned (STARÝ; SAMPAIO; BUENO, 2007). Although A. rhopalosiphi was present in the wheat crop, its population was much smaller than those of the other species, and it was found in small numbers on its host when compared with A. uzbekistanicus and $A$. ervi. Our data suggest that $A$. rhopalosiphi has a low impact on the control of aphids in wheat in Paraná.

In summary, this study recorded the occurrence of six species of aphid parasitoids in the north of the state of Paraná and, with the register of three exotic parasitoids released by BCWE, and in addition, this work confirmed the establishment of A. rhopalosiphi in Brazil. Finally, we suggest that further field investigation are necessary, because is still unknown the establishment of many species of these natural enemies on Brazilian agroecossystem.

\section{Acknowledgments}

The funding agencies CAPES and CNPq for the scholarships granted to authors O.C.B and A.T.H, respectively. The author M.V.S thanks CAPES, CNPq, and FAPESP for the financial support of the National Institute of Science and Technology of Parasitoid Hymenoptera of the Brazilian Southeast Region (Instituto Nacional de Ciência e Tecnologia dos Hymenoptera Parasitóides da Região Sudeste Brasileira - INCT-Hympar Sudeste).

\section{References}

ALVES, L. F. A.; PRESTES, T. M. V.; ZANINI, A.; DALMOLIN, M. F.; MENEZES, A. O. Controle biológico natural de pulgões (Hemiptera: Aphididae) em lavoura de trigo por parasitoides (Hymenoptera, Aphidiinae), no município de Medianeira, PR, Brasil. Semina, Londrina, v. 26, n. 2, p. 155-160, 2005.

SALVADORI, J. R.; SALLES, L. A. B. Controle biológico dos pulgões do trigo. In: PARRA, J. R. P.; BOTELHO, P. S. M.; FERREIRA, B. S. C.; BENTO, J. M. S. (Ed.). Controle biológico no Brasil: parasitóides e predadores. São Paulo, Manole, 2002, p. 427-447.

SAMPAIO, M. V.; BUENO, V. H. P.; DE CONTI, B. F. The effect of the quality and size of host aphid species on the biological characteristics of Aphidius colemani (Hymenoptera: Braconidae, Aphidiinae). European Journal of Entomology, Ceske Budejovice, v. 105, p. 489-494, 2008.

SAMPAIO, M. V.; BUENO, V. H. P.; LENTEREN, J. C. van. Preferência de Aphidius colemani Viereck (Hymenoptera: Aphidiidae) por Myzus persicae (Sulzer) e Aphis gossypii Glover (Hemiptera: Aphididae). Neotropical Entomology, Londrina, v. 30, n. 4, p. 655660, 2001.

SILVA, R. J.; BUENO, V. H. P.; SAMPAIO, M. V. Qualidade de diferentes espécies de pulgões como hospedeiros do parasitóide Lysiphlebus testaceipes (Cresson) (Hymenoptera: Braconidae, Aphidiinae). Neotropical Entomology, Londrina, v. 37, n. 2, p. 173179, 2008.

STARÝ, P.; SAMPAIO, M. V.; BUENO, V. H. P. Aphid parasitoids (Hymenoptera, Braconidae, Aphidiinae) and their associations related to biological control in Brazil. Revista Brasileira de Entomologia, Londrina, v. 51, n. 2, p. 107-118, 2007.

ZANINI, A.; ALVES, L. F. A.; MENEZES, A. O.; PRESTES, T. M. V. Aspectos ecológicos de Aphidius colemani Viereck (Hymenoptera: Aphidiidae) sobre a população de Sitobion avenae (Fabricius) (Hemiptera: Aphididae) na cultura de trigo em Medianeira, PR. Semina, Londrina, v. 27, n. 2, p. 185-198, 2006b.

ZANINI, A.; PRESTES, T. M. V.; DALMOLIN, M. F.; ALVES, L. F. A.; MENEZES, A. O. Ocorrência de Lysiphlebus testaceipes (Cresson) (Hymenoptera: Aphidiidae) parasitando pulgões (Hemiptera: Aphididae), em trigo em Medianeira, PR. Neotropical Entomology, Londrina, v. 35, n. 2, p. 275-276, 2006 a. 
